Research Article

\title{
Oceans, Lakes, and Stromatolites on Mars
}

\author{
Rhawn G. Joseph $\mathbb{D}^{1},{ }^{1}$ Olivier Planchon, ${ }^{2}$ N. S. Duxbury, ${ }^{3}$ K. Latif, ${ }^{4}$ G. J. Kidron, ${ }^{5}$ \\ L. Consorti, ${ }^{6}$ R. A. Armstrong, ${ }^{7}$ C. Gibson, ${ }^{8}$ and R. Schild ${ }^{9}$
}

${ }^{1}$ Astrobiology Research Center, Stanford, California, USA

${ }^{2}$ National Center for Scientific Research, Biogéosciences, University of Bourgogne, Dijon, France

${ }^{3}$ Department of Physics and Astronomy, George Mason University, Fairfax, VA, USA

${ }^{4}$ National Centre of Excellence in Geology, University of Peshawar, Peshawar, Khyber Pakhtunkhwa, Pakistan

${ }^{5}$ Institute of Earth Sciences, The Hebrew University of Jerusalem, Jerusalem, Israel

${ }^{6}$ Department of Mathematics and Geosciences, University of Trieste, Trieste, Italy

${ }^{7}$ Aston University, Birmingham, UK

${ }^{8}$ Scripps Institute of Oceanography, Center for Astrophysics and Space Sciences, Departments of Mechanical and Aerospace Engineering, University of California, Berkeley, CA, USA

${ }^{9}$ Department Astrophysics, Harvard-Smithsonian (Emeritus), Cambridge, MA, USA

Correspondence should be addressed to Rhawn G. Joseph; rhawnjoseph@gmail.com

Received 22 June 2020; Accepted 25 September 2020; Published 17 October 2020

Academic Editor: Michael Kueppers

Copyright (C) 2020 Rhawn G. Joseph et al. This is an open access article distributed under the Creative Commons Attribution License, which permits unrestricted use, distribution, and reproduction in any medium, provided the original work is properly cited.

\begin{abstract}
Billions of years ago, the Northern Hemisphere of Mars may have been covered by at least one ocean and thousands of lakes and rivers. These findings, based initially on telescopic observations and images by the Mariner and Viking missions, led investigators to hypothesize that stromatolite fashioning cyanobacteria may have proliferated in the surface waters, and life may have been successfully transferred between Earth and Mars via tons of debris ejected into the space following bolide impact. Studies conducted by NASA's robotic rovers also indicate that Mars was wet and habitable and may have been inhabited in the ancient past. It has been hypothesized that Mars subsequently lost its magnetic field, oceans, and atmosphere when bolides negatively impacted its geodynamo and that the remnants of the Martian seas began to evaporate and became frozen beneath the surface. As reviewed here, twenty-five investigators have published evidence of Martian sedimentary structures that resemble microbial mats and stromatolites, which may have been constructed billions of years ago on ancient lake shores and in receding bodies of water, although if these formations are abiotic or biotic is unknown. These findings parallel the construction of the first stromatolites on Earth. The evidence reviewed here does not prove but supports the hypothesis that ancient Mars had oceans (as well as lakes) and was habitable and inhabited, and life may have been transferred between Earth and Mars billions of years ago due to powerful solar winds and life-bearing ejecta propelled into the space following the bolide impact.
\end{abstract}

\section{The Oceans, Lakes, and Search for Stromatolites on Mars}

In 1784,1882 , and 1895 , and based on ground-based telescopic observations, several prominent astronomers suggested that Mars may have had oceans and rivers [1-3]; a hypothesis later supported by evidence was provided by the Mariner, Viking, and Mars Global Surveyor missions [4-10]. These findings led to suggestions, beginning in the 1970s, that water-dwelling algae (cyanobacteria) may have constructed stromatolites on the Red Planet $[9,11,12]$ and that a "search for stromatolites on Mars" should be undertaken [13]. In 2002, DiGregorio reported what he believed to be biosignatures compatible with stromatolite-building cyanobacteria in an ancient paleolake; a hypothesis was based on the detailed analysis of images from the Viking landers photographed at Utopia Planitia and Chryse Planitia. Subsequent orbital observations and ground level studies 
conducted by NASA's Mars rovers [14-20] also indicate that water repeatedly flowed and pooled upon the surface [21-26], possibly providing a habitable environment billions of years ago [16, 27-31]; a time period which coincides with the fashioning, 3.7 bya, of what may be the first stromatolites on Earth [32, 33] and Mars was reported by Noffke [34]. Specifically, Noffke [34] reported the discovery of what appear to be Martian stromatolites, constructed 3.7 bya, in a receding body of water; a finding was consistent with the observations of other investigative teams who have observed Martian sedimentary structures that resemble stromatolites that may have been fashioned in ancient paleolakes and ocean shorelines [34-43]. Many of these putative Martian stromatolites are domical and concentric in shape [38] similar to those of Lake Thetis in Western Australia (Figures 1-4) which is 2 kilometers from the Indian Ocean.

If Mars had an ocean, or if there was one ocean or two, is largely based on observations of a smooth flat lowland basin circling the Northern Hemisphere bordered by rugged highlands in the Southern Hemisphere [5, 7, 8, 44]. There is also evidence of hundreds of paleolakes and paleoshorelines in the northern lowlands [4, 45-48] and evidence of catastrophic floods [47, 49] and prograding channels, which suggest rapidly receding bodies of water [15]. The overall pattern of geologic evidence, particularly the valley networks that abound in the Noachian highlands and the fluvial and erosion pathways, is indictive of Noachian ocean [50].

\section{Bolide Impact, the Martian Geodynamo, and the Waters of Mars}

What became of the oceans and lakes of Mars is unknown. It is believed they may have become periodically frozen $[8,47,51-53]$ or assimilated as ice sheets beneath the surface and deep within the crust $[8,54,55]$, a consequence, perhaps, of the slowing and stoppage of its "geodynamo" and loss of its magnetic field around 3.7 bya (Acuña et al. $[10,56]$ ), though the actual cause and date are unknown. It has been hypothesized that massive and repeated bolide impacts may have impacted that "geodynamo" [57], thereby, causing a substantial reduction in the planet's heat flow, resulting in cooling and aridification of the climate and the loss of the magnetic shield followed by the loss of atmosphere due to powerful solar winds and UV rays [58-61]. Hence, the waters of Mars may have become frozen, and these sheets of water-ice were subsequently buried by debris $[8,51,54,55]$. Periodically, however, some of these underground reservoirs of water may percolate to the surface and saturate the atmosphere during the warmer summer months [62-64]. There is no consensus, however, and it is unknown if an ocean of water covered the Northern Hemisphere only to be replaced by lakes or if oceans and lakes coexisted, which in turn evaporated and/or seeped beneath the surface [49].

\section{The Martian Solar Habitable Zone}

That ancient Mars was wet and habitable has been documented by NASA's robotic rovers $[16,28]$. Also consistent with habitability are the presence of organics and sufficient sunlight, which could provide energy to innumerable organisms [65-67]. The ancient geochemical environment of Mars would have also provided a chemolithoautotrophic energy source $[16,68,69]$. In fact, all the necessary elements for life (i.e., C, H, N, O, P, and S) have been detected [70, 71].

The existence of liquid surface water on ancient Mars, as on Earth, is also evidence of habitability [72]. The habitable zone of a stellar system is usually defined as a circumstellar belt, inside which water can be maintained in the liquid state on the surface of a terrestrial planet orbiting that star, thereby, creating conditions favorable to life [73-75], i.e., referred to as the "Temperate Zone of the Solar System" [72]. Taking into account the influence of solar luminosity and irradiance on surface planetary temperatures [76-78], it has been estimated that the inner and outer edges of the habitable zone of the solar system are located within 0.836 and 1.656 AU from the sun [79], though the exact parameters have yet to be determined. Mars has an orbit with a semimajor axis of $1.524 \mathrm{AU}$ and an eccentricity of $0.0934 \mathrm{AU}$ [80], which means that the Red Planet orbits within the habitable zone.

The width of the continuously habitable zone since the formation of the solar system, 4.6 billion years ago, has been estimated as between 0.95 and $1.15 \mathrm{AU}$ [74, 81, 82]. If Mars had a less eccentric orbit billions of years ago and/or prior to whatever cataclysm may have negatively affected its "geodynamo" is unknown. Nevertheless, even with an axis of $1.524 \mathrm{AU}$ and an eccentricity of $0.0934 \mathrm{AU}$ [80], the Red Planet would have orbited within the habitable zone for much of the year, conditions which may also help explain the evidence of catastrophic flooding and what may be the receding and freezing of Martian oceans and lakes, i.e., a freeze-thaw cycle due to the eccentric orbit. And yet, the early atmosphere of Mars was probably much denser than at present (1.3-4 bar) and composed of $\mathrm{CO}_{2}$ and $\mathrm{H}_{2} \mathrm{O}$ in addition to $5-20 \% \mathrm{H}_{2}$ [83-85], and these gasses could have created a greenhouse effect and raised the mean annual and global surface temperature above the freezing point of water $[83,86]$. As summed up by Ramirez [87], "Although most investigators believe that the geology indicates the presence of surface water, disagreement has persisted regarding how warm and wet the surface must have been and how long such conditions may have existed. The geologic evidence is most easily explained by a persistently warm climate. Requiring only $\sim 1 \% \mathrm{H}_{2}$ and 3 bar $\mathrm{CO}_{2}$ or $\sim 20 \% \mathrm{H}_{2}$ and 0.55 bar $\mathrm{CO}_{2}$. Such that a warm and semi-arid climate remains the simplest and most logical solution to Mars paleoclimate."

Hence, although the sun may have been 20-25\% weaker [88], ancient Mars-like ancient Earth-due to its position in the circumstellar habitable zone, coupled with the presence of water on the surface and the composition of its $\mathrm{CO}_{2}$-rich atmosphere, would have been warm, wet, and habitable over 3 billion years ago [16, 61, 89-91]. A warm, wet Mars with lakes and possibly oceans upon the surface would account for the observations of twenty-five investigators who have provided evidence of Martian sedimentary structures that resemble fossilized stromatolites fashioned by cyanobacteria in ancient lakes and shorelines [35, 37-40,42,43], at least one of which may 


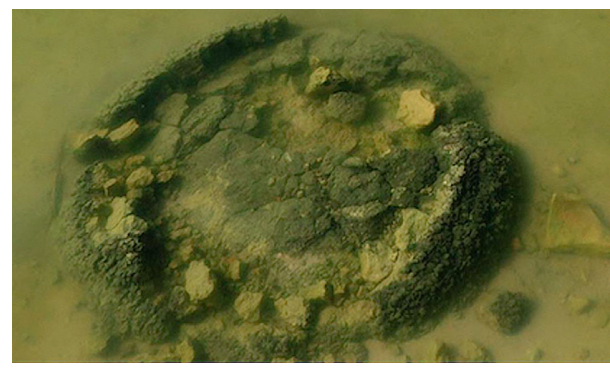

(a)

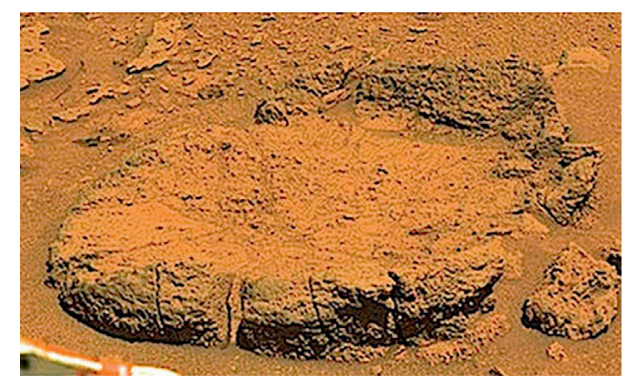

(b)

Figure 1: (a) Lake Thetis under water stromatolite (permission to reproduce photo granted by Lyn Lindfield and TheTravellingLindfields.com). (b) Sol 529: Martian specimen with evidence of concentric lamination and fossilized fenestrae (reproduced with permission from [38]).

have been constructed 3.7 bya [34], and thus, at the same time, stromatolites may have been the first formed on Earth [32, 33].

\section{Stromatolites}

The formation, growth, and structure of laminated cyanobacterial mats and their calcification and photosynthetic properties have been described in detail by previous workers [92-94]. Cyanobacteria are often assisted or accompanied by other microbes including sulfate reducing and purple bacteria, which form bacterial communities that collectively precipitate $\mathrm{CaCO}_{3}$ in shallow waters, which in turn enables them to cement together sedimentary structures $[93,95,96]$. As cyanobacteria also produce oxygen as a photosynthetic byproduct, fenestra and apertures are commonly formed in the matrix by gas bubbles; and features similar to these (Figures 5 and 6) have been observed within or adjacent to stromatolite- and bacterial mat-like formations on Mars $[34,38,41,42]$.

Stromatolites may take the form of stratified and layered mounds, columns, and sheet-like sediments that are conical, domal, stratiform, or branching - and similar sedimentary structures have been observed on Mars [38, 97]. These sediments are usually cemented together via the mucous and biofilm secretions and intertwined filaments and tendrils of cyanobacteria that bind together sand and sedimentary grains [94, 98-102].

Stromatolites are also constructed by lichens, via the alga photobiont of the lichen symbiotic consortium; and these sediments are generally formed above water, atop rocks inhabited by endolithic lichens [103, 104], and specimens resembling endolithic lichens have been observed in the paleolake beds of Eagle and Gale Crater [38, 105]. By contrast, those typically fashioned by cyanobacteria are formed along shorelines and shallow waters $[106,107]$. As algae and stromatolite-building lichens are photosynthesizing organisms, deriving their energy via sunlight [104, 108-110], water-dwellers colonize sediments and orient and clump together and on top of each other forming layers and growing towards the light $[94,103,111,112]$, thus forming sedimentary structures that rise above the water; and formations resembling those formed in shallow waters have been observed on Mars [34, 35, 38, 40, 42, 113].

A similar pattern of cementation and construction is also a characteristic of thrombolites [98-101]. Thrombolites are thick microbial mats [106] consisting of calcified cyanobacteria sheaths $[107,114-116]$ and which are cemented together via the precipitation of carbonate minerals within the mucilage [93]. These photosynthesizing microbes migrate toward the sunlight, thereby, forming layers of microbial mats [98-101]. Fossilized thrombolites/bacterial mats have also been observed on Mars [34, 38, 41, 42].

On Earth, the first evidence of stromatolites has been dated to 3.7 bya $[32,33]$-though not all investigators accept these dates. However, stromatolites and thrombolites continue to be fashioned in the present day, having been found along sea shores and reefs, fresh water lakes $[117,118]$, and in lagoons and hypersaline lakes [119-122]. Lake Thetis and other Western Australian lakes are hosts to fossilized and living domical conical stromatolites and thrombolites [112] and are believed to be analogs to Martian paleolakes lakes $[123,124]$ and the lakes of Gale Crater [38]. Specimens resembling and nearly identical to the concentric domical stromatolites of Lake Thetis have also been tentatively identified in the dried lake beds of Gale Crater $[38,113]$.

\section{Lakes in Gale Crater}

Most investigators directly involved in the exploration of Gale Crater by the rover Curiosity agree that this area was habitable early in the history of Mars and was flush with water, rivers, streams, and lakes [125-127]. Gale Crater is marked by numerous fluvial valleys, gullies, and water pathways [58, 128-130] and has all the characteristics of a series of dried lakes [16] that may be periodically replenished with water [20]. Based on morphological observations, Fairen et al. [58] described what they believed to be "evidence for ancient glacial, periglacial and fluvial (including glacio-fluvial) activity within Gale crater, and the former presence of ground ice and lakes." However, Grotzinger et al. [125] did not find periglacial evidence. Based on morphology, Oehler [130] argued that landforms indicate a "major history of water and ice in Gale crater, involving 


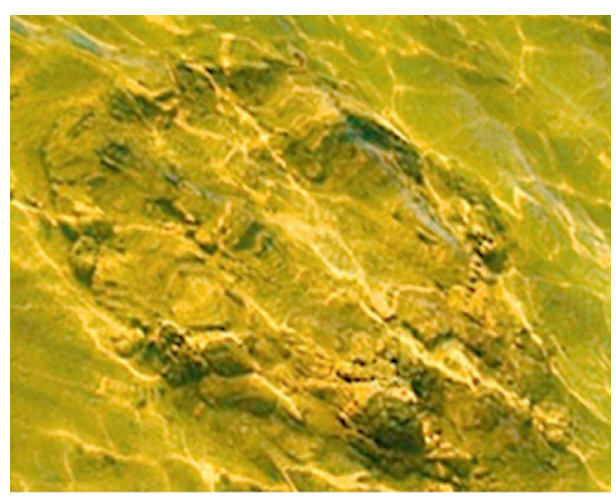

(a)

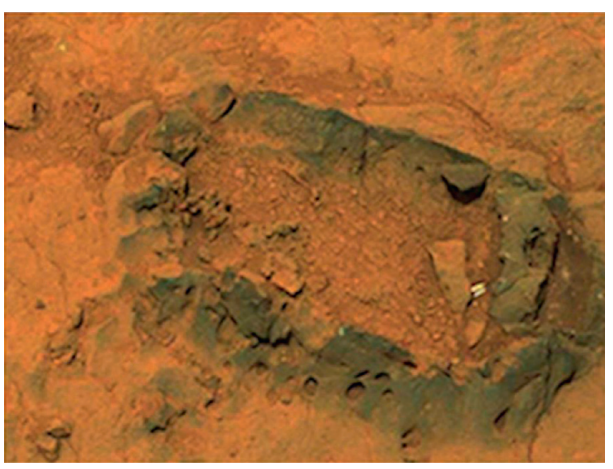

(b)

Figure 2: (a) The remains of a Lake Thetis underwater stromatolite. Photo credit: government of Western Australia department of mines and petroleum. (b) Sol 308 water pathways leading down and curving around a Martian specimen resembling a Lake Thetis stromatolite. Reproduced with permission from [38].

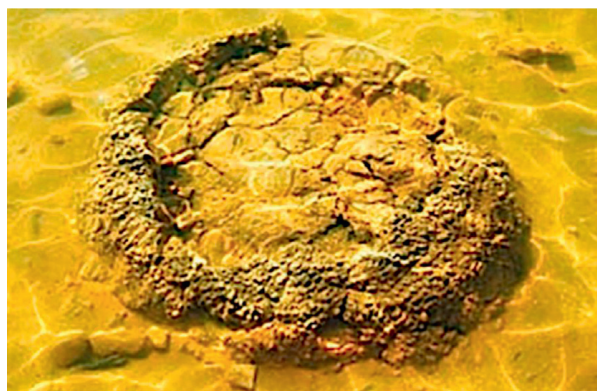

(a)

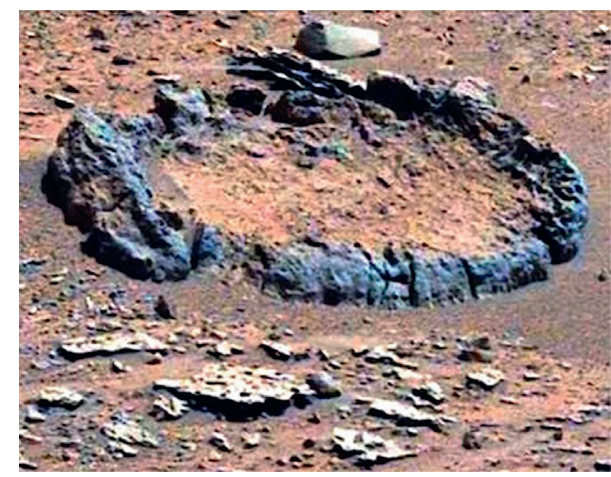

(b)

FIgURe 3: (a) Submerged Lake Thetis stromatolite. Photo credit: government of Western Australia department of mines and petroleum. (b) Sol 122: Martian specimen with collapsed dome and evidence of fossilized fenestrae within the upper portion of the walls. This specimen appears to be fossilized and displays the vertical and inward orientation typically caused by upward-migrating microbial colonies at the sediment-water interface (Figure 4). Several "peanut-brittle" specimens resembling thrombolite mats appear in the bottom portion of the photo.

permafrost, freeze-thaw cycles, and perhaps ponded surface water." Masson et al. [131] have come to similar conclusions.

There are gullies, water pathways, and deltas which are most likely formed following heavy rains or the melting of ice and snow which released rivers of water, which often flowed from north to south and deposited sediment in the numerous lakes on the crater floor $[20,125]$. These lakes may have periodically dried out, only to be replenished [63], in a cycle that may have lasted billions of years [132-135]. Water may have continued to flow into and perhaps partially filling the Gale Crater lakes, thereby replenishing the water supply repeatedly, until 145 million to a few million years ago. As summed up by Rampe et al. [20], "Evidence for a long-lived lake or lake system in Gale crater is compelling "possibly" up to the present day."

That those waters were leached from rocks, melting subsurface ice sheets, percolating upward from underground aquifers, and raining down upon the surface is also evidenced by the numerous fluvial gullies and pathways, which appear to have been fashioned by flowing liquid across the surface of Mars $([136,137])$. For example, as detected by the rover Curiosity's suite of sampling instruments, clays, mudstones, and a variety of minerals have been repeatedly hydrated [16, 27, 68, 125, 138, 139]. Therefore, Gale Crater appears to have undergone mineralization due to the presence of large amounts of water [128] and has likely repeatedly filled with water [58, 140-146].

At a minimum, therefore, the evidence indicates that ground and subsurface water may have been continuously or at least intermittently present beginning around 3.8-3.6 bya and continuing for the following 1.5 billion years $[20,26,63,147]$ and intermittently thereafter. Gale Crater therefore provided a habitable environment [16, 125]. Moreover, that environment may have been colonized by photosynthesizing cyanobacteria 3.7 bya [34].

\section{Stromatolites in Gale Crater}

If the waters and lakes that continuously or periodically filled Gale Crater were alkaline or saline is unknown, though it has been argued, based on an analysis of hydrated minerals, that 


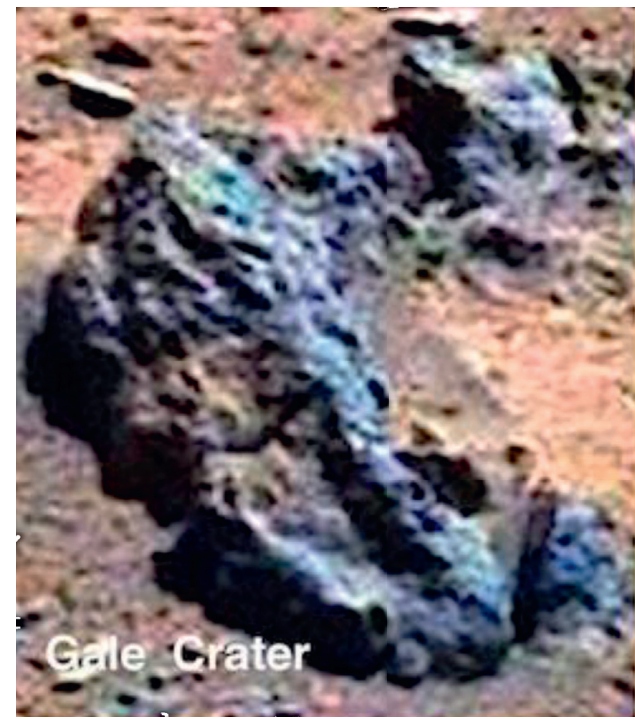

(a)

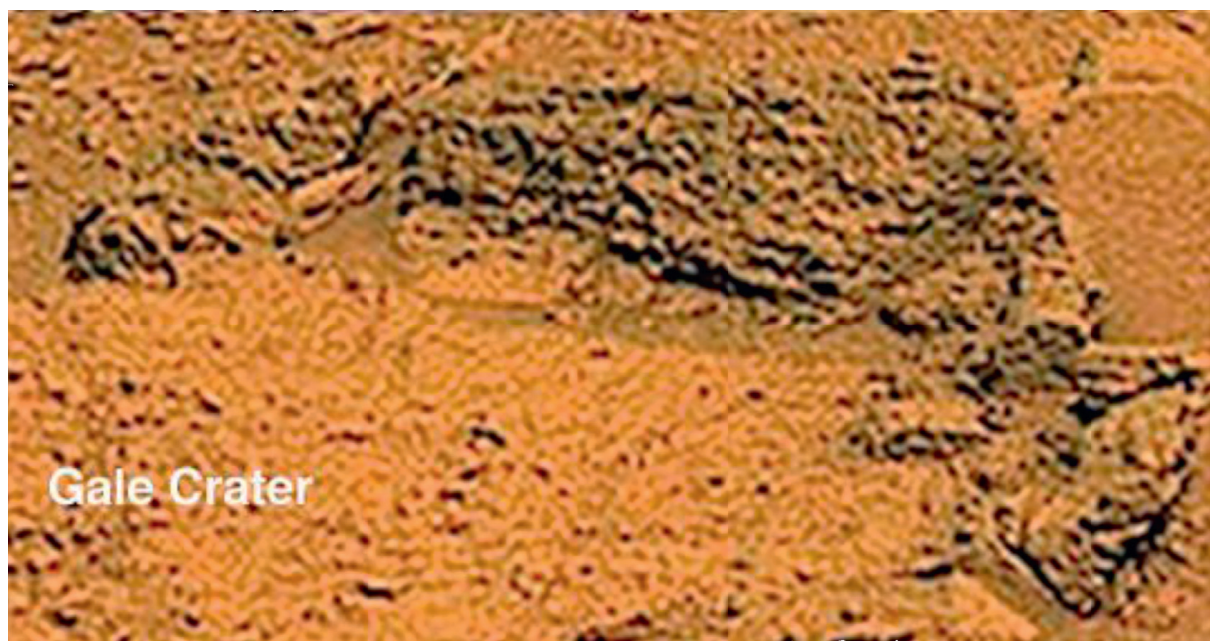

(b)

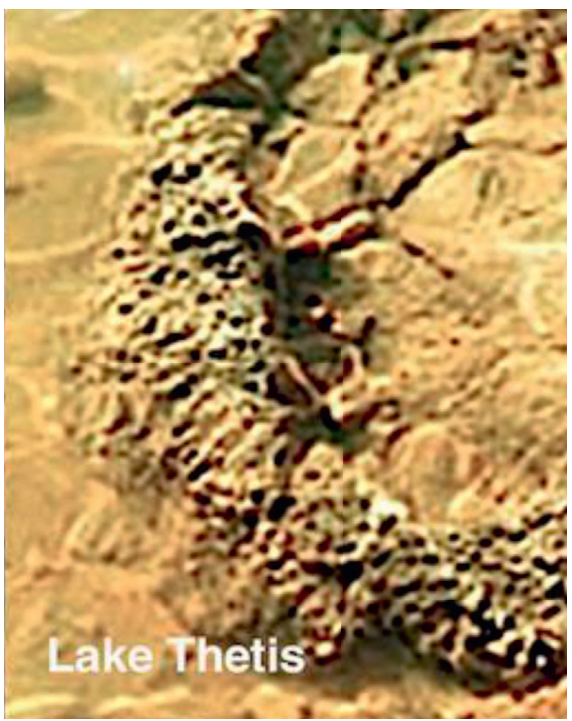

(c)

Figure 4: (a) Gale crater/sol 528 (close up of sol 122 (Figure 3). (b) Close up of sol 529. Note. Features resembling apertures, open cone-like structures, gas domes, and fenestrae. These gale crater specimens may be hundreds, thousands, or hundreds of thousands of years in age. Both appears to be fossilized and weathered. Contrast with (c) Lake Thetis living stromatolite photographed beneath the water and featuring numerous gas domes, apertures, and fenestra. 
these lakes were more alkaline than saline and similar to the lakes of Western Australia [110, 123, 124], Lake Thetis in particular [38], although if one or more of these lakes were saline or hyposaline is also a possibility [148].

Consistent with the evidence of repeated episodes of hydration followed by drying, Noffke [34] has found evidence of microbial mats in the Gale Crater, which may have formed 3.7 bya in regressive bodies of water. Specifically, Noffke [34] reported that these mats have the microstructure and morphologies and stratigraphic successions typically produced by colonies of microorganisms, i.e., "centimeter-to meter-scale structures similar in macroscopic morphology" that include "mat chips," "erosional remnants and pockets," "desiccation cracks," "roll-ups," and "gas domes" that are arranged in spatial and temporal successions similar to the "growth of a microbially dominated ecosystem that thrived in pools that later dried completely."

The microstructure of a putative Martian stromatolite photographed in the Gale Crater (Sol 506) was also found to be comparable to a terrestrial stromatolite from Lagoa Salgada, Brazil [37]. Highly organized microspherules, thrombolytic microfacies, voids, fenestrae, intertwined filaments, and layer deformation were common to both (Figures 4, 5, and 7).

In 2019, a team of 14 experts conducted an extensive search of NASA's rover Curiosity Gale Crater image depository for macrostructures, which resemble the stromatolites of Lake Thetis, and subsequently, published pictorial evidence of six concentric domical specimens, four of which are nearly identical to those of Lake Thetis [38]. Two specimens were photographed adjacent to features which resemble thrombolite bacterial mats, and a third concentric dominical formations was determined to consist of five layers of crinkly and wavy nodular laminae with several orders of curvature, an abundance of detrital material, the presence of what appears to be numerous fenestrae/gas bubbles, a central (albeit collapsed) axial zone, and features that resemble the preferential vertical, upward, and inward growth, which is typically caused by upward-migrating microbial colonies at the sediment-water interface $[112,121,122]$. Moreover, extensive nodular biological mats and thrombolites were identified on and adjacent to this specimen (Figures 40-43 in [38]), thereby, fulfilling the criteria for a biological vs. an abiogenic formation [149-152]. Rizzo [97], in a work published by the International Journal of Astrobiology, replicated some of the findings of Joseph et al. [38] and also found evidence of fenestrae and what may be fossilized algae.

A common attribute of stromatolite-like formations observed in Gale Crater is the presence of open apertures, fenestrae, and what appear to be gas domes [34, 38, 97]. Open cone-shaped apertures were also observed adjacent to formations resembling algae and lichens [38]; though if these latter specimens are alive, fossilized, or abiotic is unknown. On Earth, gas domes similar to those observed on Gale Crater (Figures 4-7) serve to vent oxygen and other gasses produced during photosynthesis [153, 154]. Therefore, it could be argued that these open apertures and fenestrae were produced via venting of oxygen produced by photosynthesis.
This evidence is consistent with orbital and ground level studies indicating that Gale Crater was home to numerous lakes and supports the hypothesis put forth by numerous investigators in the last century that stromatolites may have been fashioned in the paleolakes of the Red Planet. Moreover, formations resembling stromatolites have been observed in other areas of the Northern Hemisphere of Mars.

\section{Stromatolites and Gusev Crater Lake}

Gusev Crater may have been an ancient ice covered lake, which was fed by aquifers and subject to flooding from surrounding areas, and this watery environment may have persisted from 4.6 bya to 3.5 bya [155] followed by episodes of filing, evaporation, and drying until about 2 bya [156]. Subsequent analyses by the rover Spirit's suite of instruments found evidence of an "unequivocal interaction" between water and the rocks in the Gusev plains [157], and it was hypothesized that rain, ice, and snow have been repeatedly produced by precipitation and condensation from the atmosphere [158]. Melting of ice from beneath the surface may have also repeatedly covered the surface with water [159].

Analyses of surface rocks and regolith at Gusev Crater and the adjacent Columbia Hills indicate obvious evidence of water erosion, ranging from mild to severe [157, 160-164]. Although no current evidence of moisture, ice, or snow has been detected, it has been concluded that "Gusev Crater" may have been conducive to life on Mars in the past [165].

Gusev Crater, therefore, was an ancient habitable lake, which may have been filled or periodically filled with water from 4.6 to 3 billion years ago [156]. Those living creatures which may have dwelled in the lake may have also included stromatolite-building cyanobacteria [40].

Ruff and Farmer [40] reported evidence of what appear to be "microbially mediated micro-stromatolites" photographed by the rover Spirit. They detected biofilms, sheaths, and microstructures organized as intertwined microspherule filaments. Additional morphological analyses of sedimentary specimens resembling Gusev Crater stromatolites have also revealed microstructures organized as intertwined microspherule filaments nearly identical to those observed in Earthly microbialites [41, 42]. Like the stromatolites observed in Gale Crater, Rizzo and Cantasano [41, 42] also detected evidence of gas domes within these putatative Gusev microbialites similar to those fashioned by cyanobacteria for the venting of oxygen produced via photosynthesis. If these are in fact stromatolites, it is likely they may have been constructed over 3 billion years ago when Gusev Crater was a lake filed with water.

\section{Meridiani Planum, Water, and Stromatolites}

Investigation of Meridiani Planum soil and regolith, via the rover opportunities suite of sampling instruments, also detected considerable evidence that sediments had been deposited by flowing water [166]. The observation of sand ripples, centimeter scale cross-stratification, and festoon geometry of cross-lamination of surface features has also 


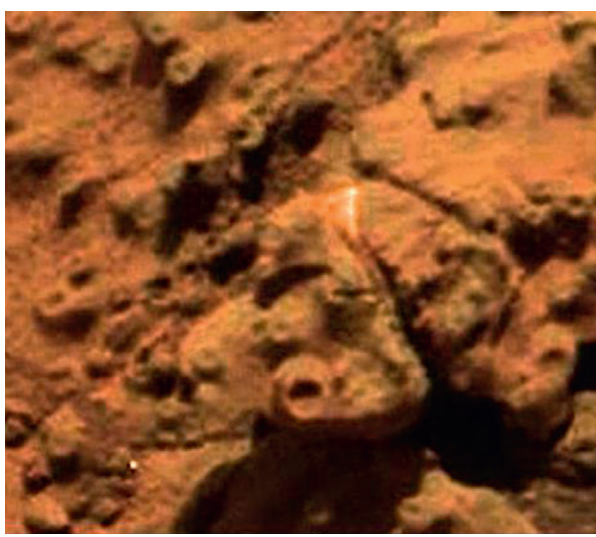

(a)

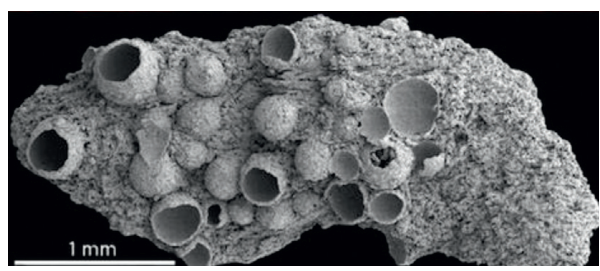

(b)

Figure 5: Gale crater/sol 232. (a) Specimens similar to open cone and gas-vent apertures formed via the release of oxygen secondary to photosynthesis. Photosynthesizing organisms respire oxygen and release gas bubbles into the surrounding matrix, thereby, fashioning these vents. Surrounding green substance may be algae/cyanobacteria ([38]; reproduced with permission). (b) Open globular structures, interpreted as formed by gas bubbles via cyanobacteria oxygen respiration within microbial mats ([153]; reproduced with permission).

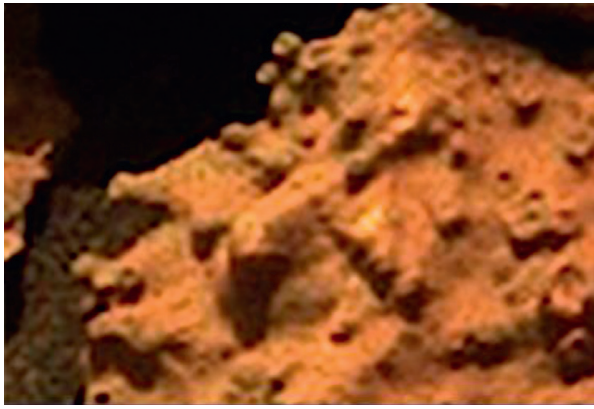

(a)

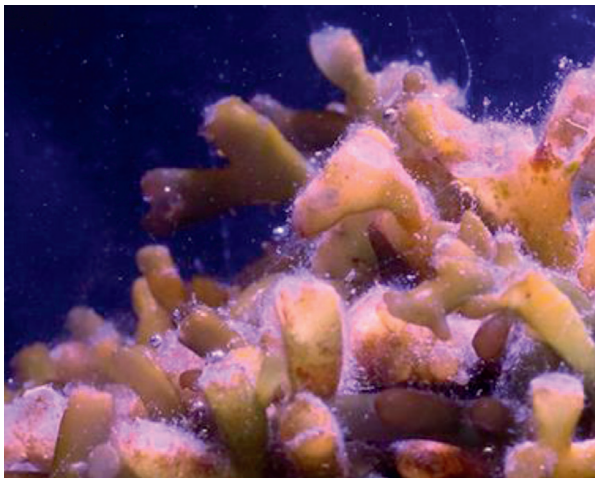

(b)

FIGURE 6: Sol 232 (a): cone-like formations that resemble gas-vent apertures for the release of oxygen secondary to photosynthesis by algae/ cyanobacteria and which appear to be moist. If they are alive, fossilized, or abiotic is unknown. (b) Cone-like tubes for the venting of oxygen produced by photosynthesizing water-dwelling algae (reproduced with permission from [31]).

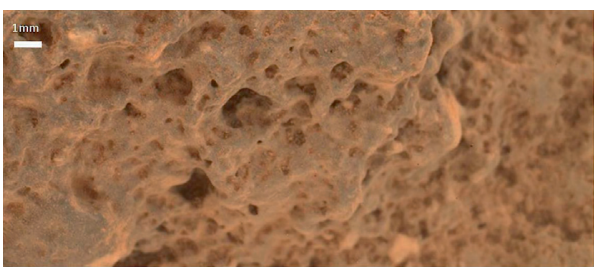

(a)

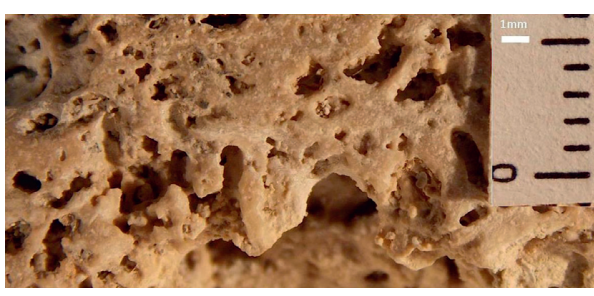

(b)

Figure 7: Microanalyses of a Martian stromatolite-like formation (a) photographed by the rover curiosity (sol 506) in gale crater compared with (b) a terrestrial stromatolite from Lagoa Salgada, Brazil. Voids, apertures, and highly organized microspherules and thrombolytic microfacies are common to both. Earthly cyanobacteria typically form voids, intertwined filaments, and layer deformation within stromatolites (reproduced with permission from [37]).

been interpreted as due to the flow of water $[18,28]$. Likewise, the presence of channels indicates that water from melting snow and "massive ice deposits" [138, 167] may have flowed downward into local basins forming numerous pools of standing water [168] between dunes of sand and which saturated the soil [169]. There have been repeated episodes of ground water inundation in Meridiani Planum [170]. Moreover, it appears that pools of water were formed from the upwelling of underground aquifers followed by evaporation, and that global groundwater flow may have been 
driven by precipitation $[140,171]$. Thus, there is considerable evidence for the flow and pooling of a significant amount of ground water at various times in the history of Meridiani Planum, including the possible formation of transient lakes in Endurance Crater [29, 172].

Squyers and Knoll [169] in summing of the data from Meridiani Planum have argued that there is "a rich record of past aqueous processes on Mars, including both subsurface and surface water. Conditions there may have been suitable for some forms of life."

Rizzo and Cantasano were the first to identify possible stromatolites/microbialites on Mars and performed a detailed microanalysis of this structure located in what they believed to be an ancient lake bed within Meridiani Planum. They observed and provided evidence of segmented sedimentary structures bordered by lamina similar to microbialites on Earth [41, 42]. Bianciardi, Rizzo, and Cantasano $[35,42]$ performed a detailed statistical, comparative, quantitative analysis of these stromatolite microstructures and which they compared to terrestrial stromatolites and microbialites. These scientists found microdomes, fenestrae, and extensive morphometric similarities in texture and organization almost identical to stromatolites constructed by cyanobacteria/algae.

In addition, formations resembling fossilized algae have been identified by Kaźmierczak [173] along the shoreline of Endurance Crater, which billions of years ago is believed to be one of the many lakes in Meridiani Planum [29].

Water-dwelling-rock colonizing lichens also construct stromatolites [103, 104], and thousands of mushroomshaped lichen-like formations have been also been observed in Meridiani Planum, within Eagle Crater [105], which some investigators believe may have been small lake [169]. These lichen-like formations form vast colonies and are attached to rocks by thin stems and oriented skyward similar to photosynthesizing organisms. If these lichen-like specimens are abiotic, living, or fossilized is unknown.

\section{The Waters of Utopia and Chryse Planitia}

The Viking Landers touched down at Utopia Planitia and Chryse Planitia, in 1976. Condensation and sublimation of ground frost was observed [174], and water within regolith was a detected via Viking's mass spectrometers [175]. The presence of frost and water indicates that Utopia and Chryse Planitia could provide a habitable environment for extremophiles adapted to extremely cold environments, including fungi, lichens, and a variety of archae and bacteria. Utopia and Chryse Planitia are also believed to be ancient paleolakes [142] and may have and may still provide a habitable environment for algae [176].

DiGregorio [177], upon examining the 1976 Mars Viking images, observed what he interpreted to be "rock varnish" typically produced by a wide variety of microorganisms "including epilithic and endolithic cyanobacteria." DiGregorio hypothesized that cyanobacteria may have cemented sediments together, fashioning microbial mats and stromatolites in these ancient Martian lakes.

\section{Early Life on Earth: Parallels with Mars}

Although considered controversial [178, 179], evidence of biological residue, carbonates, chains of magnetite, and fossilized polycyclic aromatic hydrocarbons (PAHs) have been discovered in ALH 84001 [12, 180, 181]. It has been argued that at least $25 \%$ of the organic residue is biological [30] and can be dated to at least 3.8 bya to 4.2 bya $[30,182]$.

Prior to ejection into the space, ALH likely originated in a watery environment $[30,183]$ and was subject to numerous episodes of aqueous activity [184], with wet followed by dry spells and with water levels "gradually evaporating" [183]. As noted, sedimentary structures similar to stromatolites, dated to 3.7 billion years in age and which was fashioned in and exposed to a receding volume of water, have also been reported [34].

These findings-which are by no means conclusive-indicate that life may have appeared on Mars, between 3.7 bya and 4.2 bya, thus paralleling the emergence of Earthly life as indicated by the high concentrations of carbon 12 [185], the presence of graphite $[186,187]$ and carbon-isotopes and organic carbon discovered in apatite and quartz-pyroxene, and carbon-related evidence interpreted as the residue of photosynthesis, oxygen secretion, and biological activity dated to 3.8 bya to 4.2 bya [188-192] Additional probable isotopic biosignatures have been identified in sulfur [188], nitrogen [193], and iron formations [194, 195], all dated to at least 3.8 bya.

Evidence indicative of fossilized fungi [196] and eukaryotic algae [197] have also been observed in sediments dated 3.8 bya-though not all investigators accept this evidence. In addition, remnants of ancient stromatolites that were fashioned in shallow water have been found in metacarbonate rocks aged 3.7 bya [33]. On Earth, the first stromatolites, therefore, may have been fashioned beginning around 3.7 bya $[32,33]$ most likely by algae (cyanobacteria)-though not all investigators agree with these dates.

\section{The Interplanetary Transfer of Life}

As reviewed in this report, there is evidence that life took root on a watery Earth and, possibly, on a warm watery Mars, early in the history of both planets, and these life forms may have been building stromatolites beginning 3.7 bya. The evidence suggestive of parallels in the origins of life on both planets supports the hypothesis that life on Earth and Mars may have originated from outside this solar system [198-200], and that these planets may have been colonized when first forming as protoplanets [113]. These scenarios would account for why there are chemical fossils on both planets suggesting that even as the earliest rocks were solidifying during the heavy bombardment, 4.2 bya, there was already evidence of life ([113]. It is also equally likely that life was delivered via meteors, asteroids, comets, and oceans of frozen water, during the heavy bombardment phase between 3.8 bya and 4.2 bya [201, 202], and/or that life-infested rocks, boulders, and mountains of soil were repeatedly ejected and transferred between Earth and Mars via meteor strikes 
[192, 203-207] and powerful solar winds blowing upper atmospheric spores into the space $[201,208]$-conditions under which algae, fungi, lichens, spores, and other microbes can survive [209-212].

Therefore, Mars and Earth may have been repeatedly seeded with life from outside this solar system and/or repeatedly exchanged life early in the history of both planets. This would account for evidence that life may have appeared simultaneously on Mars and Earth 4.2 bya, why stromatolites may have been constructed on both worlds 3.7 bya, and why specimens similar to algae, fungi, and lichens may be common to both planets.

\section{Conclusions}

Mars may have been a wet, habitable planet billions of years ago. In the last century, a number of scientists hypothesized that stromatolite-constructing cyanobacteria may have colonized Mars and urged that a search for these sedimentary structures should be undertaken. Subsequently, twenty-five investigators have published evidence of microstructures and macrostructures, photographed on Mars, which resemble stromatolites fashioned on Earth and in Lake Thetis in particular. If these Martian specimens are biological in origin is not known with absolute certainty as not all terrestrial stromatolites and thrombolites are biological $[151,152,213,214]$. Therefore, the evidence reviewed here does not prove but supports the hypothesis that ancient Mars had oceans and lakes and was habitable and inhabited by organisms, which may have constructed stromatolites.

\section{Data Availability}

The data used to support this study are included within this article.

\section{Conflicts of Interest}

The authors declare that they have no conflicts of interest.

\section{Authors' Contributions}

All authors have either contributed directly to the research reviewed and/or assisted in the analysis, writing, editing, and/in searching for and referencing the works cited.

\section{Acknowledgments}

The authors thank Dr. V. Rizzo and Dr. G. Bianciardi for the helpful comments.

\section{References}

[1] W. Herschel, "On the remarkable appearances at the polar regions of the planet Mars, and its spheroidical figure; with a few hints relating to its real diameter and atmosphere," Philosophical Transactions of the Royal Society, vol. 74, p. 233, 1784.

[2] G. V. Schiaparelli, “Observatory 5 221," 1882.

[3] P. Lowell, "Mars houghton mifflin," 1895.
[4] M. H. Carr, The Surface of Mars, Cambridge University Press, Cambridge, UK, 2007.

[5] N. S. Duxbury, Estimating the Past Martian Ocean Depth, European Geophysical Society, Nice, France, 2000.

[6] M. C. K. S. Malin, "Oceans or seas in the martian northern lowlands: high resolution imaging tests of proposed coastlines," Geophysical Research Letters, vol. 26, no. 19, pp. 3049-3052, 1999.

[7] T. J. Parker, Symposium on Mars: Evolution of its Climate and Atmosphere, Lunar \& Planetary Institute, Houston, TX, USA, 1986.

[8] J. W. Head, "Possible ancient oceans on mars: evidence from mars orbiter laser altimeter data," Science, vol. 286, p. 2134, 1999.

[9] C. Sagan and G. Mullen, "Earth and mars: evolution of atmospheres and surface temperatures," Science, vol. 177, no. 4043, pp. 52-56, 1972.

[10] M. H. Acuña, J. E. P. Connerney, N. F. Ness et al., "Global distribution of crustal magnetization discovered by the mars global surveyor MAG/ER experiment," Science, vol. 284, pp. 790-793, 1999.

[11] V. C. Tewari, "Earliest microbes on earth and possible occurrence of stromatolites on mars," in Exobiology: Matter, Energy, and Information in the Origin and Evolution of Life in the Universe, J. Chela-Flores and F. Raulin, Eds., Springer, Dordrecht, Netherlands, 1998.

[12] D. S. McKay, "Search for past life on Mars: possible relic biogenic activity in martian meteorite ALH84001," Science, vol. 273, pp. 924-930, 1996.

[13] M. R. Walter, "Fossil life on mars," in Exobiology and Future Mars Missions, C. McKay, Ed., NASA, Washington, DC, USA, Article ID 10027, 1988.

[14] S. Duran, T. J. Coulthard, and E. R. C. Baynes, "Knickpoints in martian channels indicate past ocean levels," Scientific Reports, vol. 9, no. 15153, 2019.

[15] P. Fawdon, S. Gupta, J. M. Davis et al., "The Hypanis valles delta: the last highstand of a sea on early Mars?" Earth and Planetary Science Letters, vol. 500, pp. 225-241, 2018.

[16] J. P. Grotzinger, "A habitable fluvio-lacustrine environment at yellowknife bay, gale crater, mars," Science, vol. 343, 2014.

[17] J. M. Metz, J. P. Grotzinger, D. Mohrig et al., "Sublacustrine depositional fans in southwest melas Chasma," Journal of Geophysical Research E: Planets, vol. 114, no. 10, Article ID E10002, 2009.

[18] J. P. J. F. Grotzinger, W. Calvin, B. C. Clark et al., "Stratigraphy and sedimentology of a dry to wet eolian depositional system, burns formation, meridiani planum, Mars," Earth and Planetary Science Letters, vol. 240, pp. 11-72, 2005.

[19] F. Poulet, J.-P. Bibring, J. F. Mustard et al., "Phyllosilicates on Mars and implications for early Mars climate," Nature, vol. 438, pp. 623-627, 2005.

[20] E. B. Rampe, "Mineralogy and geochemistry of sedimentary rocks and eolian sediments in gale crater, Mars: a review after six Earth years of exploration with curiosity," Geochemistry, vol. 80, Article ID 125605, 2020.

[21] A. D. Howard, J. Moore, and R. P. Irwin, "An intense terminal epoch of widespread fluvial activity on early mars: 2 . Increased runoff and paleolake development," JGR Planets, vol. 110, 2005.

[22] R. P. Irwin, A. D. Howard, R. A. Craddock, and J. Moore, "An intense terminal epoch of widespread fluvial activity on early Mars: 2," Increased runoff and paleolake development, vol. 110, 2005. 
[23] C. J. Barnhart, A. D. Howard, and J. M. Moore, "Long-term precipitation and late-stage valley network formation: landform simulations of parana basin, Mars," Journal of Geophysical Research: Planets, vol. 114, 2009.

[24] B. M. Hynek, M. Beach, and M. R. T. Hoke, "Updated global map of martian valley networks and implications for climate and hydrologic processes," Journal of Geophysical Research: Planets, vol. 115, Article ID E09008, 2010.

[25] Y. Matsubara, A. D. Howard, and J. P. Gochenour, "Hydrology of early mars: valley network incision," Journal of Geophysical Research: Planets, vol. 118, pp. 1365-1387, 2013.

[26] R. M. Ramirez and R. A. Craddock, "The geological and climatological case for a warmer and wetter early mars," Nature Geoscience, vol. 11, no. 4, pp. 230-237, 2018.

[27] B. L. Ehlmann, J. F. Mustard, S. L. Murchie et al., "Subsurface water and clay mineral formation during the early history of Mars," Nature, vol. 479, pp. 53-60, 2011.

[28] S. W. Squyres, J. P. Grotzinger, R. E. Arvidson et al., "In situ evidence for an ancient aqueous environment at Meridiani Planum, mars," Science, vol. 306, no. 5702, pp. 1709-1714, 2004.

[29] S. W. Squyres, "Two years at Meridiani Planum: results from the opportunity rover," Science, vol. 313, pp. 1403-1407, 2006.

[30] K. L. Thomas-Keprta, "Origins of magnetite nanocrystals in martian meteorite ALH84001," Geochimica et Cosmochimica Acta, vol. 73, pp. 6631-6677, 2009.

[31] S. E. Freeman, L. A. Freeman, G. GHioroli, and A. F. Haas, "Photosynthesis by marine algae produces sound, contributing to the daytime soundscape on coral reefs," PLoS One, vol. 13, 2018.

[32] R. J. Garwood, "Patterns in palaeontology: the first 3 billion years of evolution," Palaeontology Online, vol. 2, no. 11, pp. 1-14, 2012.

[33] A. P. Nutman, V. C. Bennett, C. R. L. Friend, M. J. Van Kranendonk, and A. R. Chivas, "Rapid emergence of life shown by discovery of 3,700-million-year-old microbial structures," Nature, vol. 537, pp. 535-538, 2016.

[34] N. Noffke, "Ancient sedimentary structures in the $<3.7 \mathrm{~b} \cdot \mathrm{Ga}$ gillespie lake member, mars, that compare in macroscopic morphology, spatial associations, and temporal succession with terrestrial microbialites," Astrobiology, vol. 15, no. 2, pp. 1-24, 2015.

[35] G. Bianciardi, V. Rizzo, and N. Cantasano, "Opportunity rover's image analysis: microbialites on mars?" International Journal of Aeronautical and Space Sciences, vol. 15, no. 4, pp. 419-433, 2014.

[36] G. Bianciardi, V. Rizzo, M. E. Farias, and Cantasano, "Microbialites at gusev craters, mars," Astrobiology Outreach, vol. 2, p. 5, 2015.

[37] R. G. Joseph, R. S. Dass, V. Rizzo, N. Cantasano, and G. Bianciardi, "Evidence of life on mars?," in Journal of Astrobiology and Space Science Reviews Reprinted in Astrobiology Perspectives on Life of the Universe, M. Beech, R. Gordon, and J. Seckbach, Eds., vol. 1, pp. 40-81, Wiley-Scrivener, Beverly, MA, USA, 2019.

[38] R. Joseph, L. Graham, B. Budel et al., "Mars: algae, lichens, fossils, minerals, microbial mats and stromatolites, in Gale crater," Journal of Astrobiology and Space Science Reviews, vol. 3, no. 1, pp. 40-111, 2020.

[39] H. Rabb, Life on Mars, University of Nevada, Reno, NV, USA, 2018.

[40] S. W. Ruff and J. D. Farmer, "Silica deposits on Mars with features resemblinghot spring biosignatures at El Tatio in
Chile," Nature Communications, vol. 7, Article ID 13554, 2016.

[41] V. Rizzo and N. Cantasano, "Possible organosedimentary structures on Mars," International Journal of Astrobiology, vol. 8, no. 4, pp. 267-280, 2009.

[42] V. Rizzo and N. Cantasano, "Structural parallels between terrestrial microbialites and Martian sediments," International Journal of Astrobiology, vol. 16, 2016.

[43] L. W. Small, "On debris flows and mineral veins-where surface life resides on mars," 2015, https://www.scribd.com/ doc/284247475/On-Debris-Flows-eBook.

[44] M. A. Ivanov, "Mud volcanism and morphology of impact craters in utopia planitia on mars: evidence for the ancient ocean," Icarus, vol. 228, p. 121, 2014.

[45] N. S. Duxbury, I. A. Zotikov, K. H. Nealson, V. E. Romanovsky, and F. Carsey, "A numerical model for an alternative origin of lake vostok and its exobiological implications for mars," Journal of Geophysical Research-Planets, vol. 106, no. 1, pp. 1453-1462, 2001.

[46] D. H. Scott, The New Geologic Map of Mars, United States Geological Survey, Reston, VI, USA, 1995.

[47] A. G. Fairén, "Episodic flood inundations of the northern plains of Mars," Icarus, vol. 165, p. 53, 2003.

[48] M. H. Carr and J. W. Head, "Martian surface/near-surface water inventory: sources, sinks, and changes with time," Geophysical Research Letters, vol. 42, p. 726, 2015.

[49] Z. I. Dickeson and J. M. Davis, "Martian oceans," Astronomy \& Geophysics, vol. 61, pp. 11-17, 2020.

[50] R. M. Ramirez, R. A. Craddock, and T. Usui, "Climate simulations of early mars with estimated precipitation, runoff, and erosion rates," JGR Planets, vol. 125, 2020.

[51] C. T. Barnhart, "Lunar and planetary science," in Proceedings of the 36th Annual Lunar and Planetary Science Conference, Houston, TX, USA, 2005.

[52] N. S. Duxbury, I. A. Zotikov, and K. H. Nealson, "A nonbasal-melting origin of the possible sub-polar water on mars as derived from lake vostok modeling and mola data," Bulletin of the American Astronomical Society, vol. 31, 1999.

[53] C. Woodworth-Lynas and J. Y. Guigné, "Ice keel scour marks on mars: evidence for floating and grounding ice floes in kasei valles," Oceanography, vol. 16, p. 90, 2003.

[54] D. C. Barker and J. P. Bhattacharya, "Sequence stratigraphy on an early wet Mars Planet," Space Science, vol. 151, p. 97, 2018.

[55] P. Janhunen, "Are the northern plains of Mars a frozen ocean?” Journal of Geophysical Research: Planets, vol. 107, p. $1035,2002$.

[56] J. Arkani-Hamed and D. Boutin, "Paleomagnetic poles of mars: revisited," Journal of Geophysical Research, vol. 109, Article ID E03011, 2004.

[57] J. H. Roberts, R. J. Lillis, and M. Manga, "Giant impacts on early Mars and the cessation of the martian dynamo," Journal of Geophysical Research: Planets, vol. 114, no. 4, p. E04009, 2009.

[58] A. G. Fairén, "Icy Mars lakes warmed by methane," Nature Geoscience, vol. 10, pp. 717-718, 2017.

[59] S. M. Clifford and T. J. Parker, "The evolution of the Martian hydrosphere: implications for the fate of a primordial ocean and the current state of the northern plains," Icarus, vol. 154, pp. 40-79, 2001.

[60] N. Mangold, "A chronology of early Mars climatic evolution from impact crater degradation," Journal of Geophysical Research, vol. 117, Article ID E04003, 2012. 
[61] E. S. Kite, D. P. Mayer, S. A. Wilson, J. M. Davis, A. S. Lucas, and G. Stucky De Quay, "Persistence of intense, climatedriven runoff late in Mars history," Science Advances, vol. 5, p. 8, 2019.

[62] A. A. Fedorova, F. Montmessin, O. Korablev et al., "Stormy water on Mars: the distribution and saturation of atmospheric water during the dusty season," Science, vol. 367, 2020.

[63] P. E. Martin, "A two-step k-ar experiment on mars: dating the diagenetic formation of jarosite from amazonian groundwaters," JGR Planets, vol. 122, pp. 2803-2818, 2017.

[64] L. J. Steele, "The water cycle and regolith-atmosphere interaction at gale crater, Mars," Icarus, vol. 289, pp. 56-79, 2017.

[65] H. B. Franz, P. R. Mahaffy, C. R. Webster et al., "Indigenous and exogenous organics and surface-atmosphere cycling inferred from carbon and oxygen isotopes at gale crater," Nature Astronomy, vol. 4, 2020.

[66] J. L. Eigenbrode, "Organic matter preserved in 3-billionyear-old mudstones at gale crater, Mars," Science, vol. 360, pp. 1096-1101, 2018.

[67] C. Szopa, "First detections of dichlorobenzene isomers and trichloromethylpropane from organic matter indigenous to mars mudstone in gale crater, mars: results from the sample analysis at mars instrument onboard the curiosity rover," Astrobiology, vol. 20, pp. 292-306, 2020.

[68] D. T. Vaniman, D. L. Bish, D. W. Ming et al., "Mineralogy of a mudstone at yellowknife bay, gale crater, mars," Science, vol. 343, no. 6169, 2014.

[69] T. F. Bristow, "The origin and implications of clay minerals from yellowknife bay, gale crater, mars," American Mineralogist, vol. 100, pp. 824-836, 2015.

[70] S. M. McLennan, "Elemental geochemistry of sedimentary rocks at yellowknife bay, 558 Gale crater, mars," Science, vol. 343, no. 6169, Article ID 1244734, 2014.

[71] D. W. Ming, P. D. Archer, D. P. Glavin et al., "Volatile and organic compositions of sedimentary rocks in yellowknife bay, gale crater, mars," Science, vol. 343, no. 6169, Article ID 1245267, 2014.

[72] R. Heller and J. Armstrong, "Superhabitable worlds," Astrobiology, vol. 14, 2014.

[73] J. F. Kasting, "Runaway and moist greenhouse atmospheres and the evolution of Earth and Venus," Icarus, vol. 74, pp. 472-494, 1998.

[74] J. F. Kasting, D. P. Whitmire, and R. T. Reynolds, "Habitable zones around main sequence stars," Icarus, vol. 101, no. 1, pp. 108-128, 1993.

[75] S. I. Rasool and C. de Bergh, "The runaway greenhouse and the accumulation of $\mathrm{CO}_{2}$ in the venus atmosphere," Nature, vol. 226, pp. 1037-1039, 1970.

[76] D. R. Underwood, B. W. Jones, and P. N. Sleep, "The evolution of habitable zones during stellar lifetimes and its implications on the search for extraterrestrial life," International Journal of Astrobiology, vol. 2, no. 4, pp. 289-299, 2003.

[77] B. W. Jones and P. N. Sleep, "Habitability of exoplanetary systems with planets observed in transit," Monthly Notices of the Royal Astronomical Society, vol. 407, pp. 1259-1267, 2010.

[78] M. Turbet, D. Ehrenreich, C. Lovis, E. Bolmont, and T. Fauchez, "The runaway greenhouse radius inflation effect: an observational diagnostic to probe water on Earth-size planets and test the habitable zone concept," Astronomy \& Astrophysics, vol. 628, no. 12, p. 9, 2019.
[79] S. R. Kane and D. Gelino, "The habitable Zone and extreme planetary orbits," Astrobiology, vol. 12, no. 10, pp. 940-945, 2012.

[80] J. L. Simon, P. Bretagnon, J. Chapront, M. Chapront-Touze, G. Grancou, and J. Laskar, "Numerical expressions for precession formulae and mean elements for the moon and the planets," Astron. Astrophys,vol. 282, pp. 663-683, 1994.

[81] R. K. Kopparapu, "A revised estimate of the occurrence rate of terrestrial planets in the habitable zones around kepler m-dwarfs," The Astrophysical Journal Letters, vol. 767, 2012.

[82] R. M. Ramirez, "A more comprehensive habitable zone for finding life on other planets," Geosciences, vol. 8, no. 8, p. 280, 2018.

[83] R. M. Ramirez, R. Kopparapu, M. E. Zugger, T. D. Robinson, R. Freedman, and J. F. Kasting, "Warming early mars with $\mathrm{CO}_{2}$ and $\mathrm{H}_{2}$," Nature Geoscience, vol. 7, pp. 59-63, 2014.

[84] R. Wordsworth, Y. Kalugina, S. Lokshtanov et al., "Transient reducing greenhouse warming on early Mars," Geophysical Research Letters, vol. 44, pp. 665-671, 2017.

[85] M. Turbet, C. Boulet, and T. Karman, "Measurements and semi-empirical calculations of $\mathrm{CO}_{2}+\mathrm{CH}_{4}$ and $\mathrm{CO}_{2}+\mathrm{H}_{2}$ collision-induced absorption across a wide range of wavelengths and temperatures: application for the prediction of early Mars surface temperature," Icarus, vol. 346, 2020.

[86] N. Batalha, S. D. Domagal-Goldman, R. Ramirez, and J. F. Kasting, "Testing the early Mars $\mathrm{H}_{2}-\mathrm{CO}_{2}$ greenhouse hypothesis with a 1-D photochemical model," Icarus, vol. 258, pp. 337-349, 2015.

[87] R. M. Ramirez, "A warmer and wetter solution for early Mars and the challenges with transient warming," Icarus, vol. 297, pp. 71-82, 2017.

[88] D. O. Gough, "Solar interior structure and luminosity variations," Solar Physics, vol. 74, pp. 21-34, 1981.

[89] A. D. Del Genio, D. Brain, L. Noack, and L. Schaefer, "The inner solar system's habitability through time," in Planetary Astrobiology, V. Meadows, Ed., University of Arizona, Tucson, AZ, USA, pp. 419-447, 2020.

[90] J. M. Davis, M. Balme, P. M. Grindrod, R. M. E. Williams, and S. Gupta, "Extensive noachianfluvial systems in arabia terra: implications for early martian climate," Geology, vol. 44, 2016.

[91] F. Westall, F. Foucher, N. Bost et al., "Biosignatures on mars: what, where, and how? implications for the search for martian life," Astrobiology, vol. 15, no. 11, 2015.

[92] C. Dupraz, R. P. Reid, O. Braissant, A. W. Dech, R. S. Norman, and P. T. Visscher, "Processes of carbonate precipitation in modern microbial mats," Earth-Science Reviews, vol. 96, pp. 141-162, 2009.

[93] J. Kaźmierczak, T. Fenchel, M. Kühl et al., "CaCO3 precipitation in multilayered cyanobacterial mats: clues to explain the alternation of micrite and sparite layers in calcareous stromatolites," Life, vol. 5, pp. 744-769, 2015.

[94] R. Riding, "The term stromatolite: towards an essential definition," Lethaia, vol. 32, no. 4, pp. 321-330, 2007.

[95] M. S. Andres, D. Y. Sumner, R. P. Reid, and P. K. Swart, "Isotopic fingerprints of microbial respiration in aragonite from Bahamas stromatolites,” Geology, vol. 34, pp. 973-976, 2005.

[96] I. A. Bundeleva, L. S. Shirokova, P. Bénézeth, O. S. Pokrovsky, E. I. Kompantseva, and S. Balor, "Calcium carbonate precipitation by anoxygenic phototrophic bacteria," Chemical Geology, vol. 291, pp. 116-131, 2012.

[97] V. Rizzo, "Why should geological criteria used on Earth not be valid also for Mars? evidence of possiblemicrobialites and 
algae in extinct martian lakeslakes," International Journal of Astrobiology, vol. 1, 2020.

[98] A. S. Louyakis, J. M. Mobberley, B. E. Vitek et al., “A study of the microbial spatial heterogeneity of bahamian thrombolites using molecular, biochemical, and stable isotope analyses," Astrobiology, vol. 17, pp. 413-430, 2017.

[99] A. S. Louyakis, H. Gourlè, G. Casaburi, R. M. E. Bonjawo, A. A. Duscher, and J. S. Foster, "A year in the life of a thrombolite: comparative metatranscriptomics reveals dynamic metabolic changes over diel and seasonal cycles," Environmental Microbiology, vol. 20, no. 2, pp. 842-861, 2018.

[100] J. M. Mobberley, C. L. M. Khodadad, and J. S. Foster, "Metabolic potential of lithifying cyanobacteria-dominated thrombolytic mats," Photosynthesis Reserch, vol. 118, pp. 125-140, 2013.

[101] J. M. Mobberley, C. L. Khodadad, P. T. Visscher, R. P. Reid, P. Hagan, and J. S. Foster, "Inner workings of thrombolites: spatial gradients of metabolic activity as revealed by metatranscriptome profiling," Scientific Report, vol. 5, Article ID 12601, 2015.

[102] L. J. Stal, "Cyanobacterial mats and stromatolites," in Ecology of Cyanobacteria II: Their Diversity in Space and Time, B. A. Whitton, Ed., pp. 65-125, Springer, Dordrecht, Netherlands, 2012.

[103] A. A. M. Gorbushina, H.-J. Krumbein, and M. Vendrell-Saz, "Biogenic forsterite and opal as a product of biodeterioration and lichen stromatolite formation in table mountain systems (tepuis) of Venezuela," Geomicrobiology Journal, vol. 18, no. 1, pp. 117-132, 2001.

[104] C. F. Klappa, "Lichen stromatolites; criterion for subaerial exposure and a mechanism for the formation of laminar calcretes (caliche)," Journal of Sedimentary Research, vol. 49, no. 2, pp. 387-400, 1979.

[105] R. Joseph, R. Armstrong, G. Kidron, C. H. Gibson, and R. Schild, "Life on mars? colonies of mushroom-shaped specimens in eagle crater," Journal of Astrobiology and Space Science Research, vol. 5, pp. 88-126, 2020.

[106] G. Arp, A. Reimer, and J. Reitner, "Microbialite formation in seawater of increased alkalinity," Journal of Sedimentary Research, vol. 73, pp. 105-127, 2003.

[107] R. Riding, "Microbial carbonates: the geological record of calcified bacterial-algal mats and biofilms," Sedimentology, vol. 47, no. 1, pp. 179-214, 2000.

[108] R. A. Armstrong, "The influence of the frequency of wetting and drying on the radial growth of three saxicolous lichens in the field," New Phytologist, vol. 77, pp. 719-724, 1976.

[109] R. A. Armstrong, "Field experiments on the dispersal, establishment and colonization of lichens on a slate rock surface," Environmental and Experimental Botany, vol. 21, pp. 116-120, 1981.

[110] L. E. Graham, J. M. Graham, L. W. Wilcox, and M. E. Cook, Algae, LJLM Press, Madison, WI, USA, 2016.

[111] B. A. Biddanda, A. C. McMillan, S. A. Long, M. J. Snider, and A. D. Weinke, "Seeking sunlight: rapid phototactic motility of filamentous mat-forming cyanobacteria optimize photosynthesis and enhance carbon burial in lake huron's submerged sinkholes," Frontiers in Microbiology, vol. 6, p. 930, 2015.

[112] N. Planavsky and K. Grey, "Stromatolite branching in the neoproterozoic of the centralian superbasin, Australia: an example of shifting sedimentary and microbial control of stromatolite morphology," Geobiology, vol. 6, pp. 33-45, 2008 .
[113] R. Joseph, O. Planchon, C. Gibson, and R. Schild, "Seeding the solar system with life," Open Astronomy, 2020.

[114] L. C. Kah and R. Riding, "Mesoproterozoic carbon dioxide levels inferred from calcified cyanobacteria," Geology, vol. 35, pp. 799-802, 2007.

[115] R. Riding, "Calcified cyanobacteria," in Calcareous Algae and Stromatolites, R. Riding, Ed., pp. 55-87, Springer, Berlin, Germany, 1991.

[116] R. Riding, "Calcified cyanobacteria," in Encyclopedia of Geobiology, J. Reitner and V. Thiel, Eds., pp. 211-223, Springer, Berlin, Germany, 2011.

[117] C. Braithwaite, "Living hydromagnesite stromatolites from Turkey," Sedimentary Geology, vol. 106, no. 3-4, p. 309, 1996.

[118] E. Gischler, M. Gibson, and W. Oschmann, "Giant holocene freshwater microbialites, laguna bacalar, quintana roo, Mexico," Sedimentology, vol. 55, no. 5, pp. 1293-1309, 2008.

[119] M. Feldmann and J. A. McKenzie, "Stromatolite-thrombolite associations in a modern environment, lee stocking island, Bahamas," Palaios, vol. 13, no. 2, pp. 201-212, 1998.

[120] K. A. Rasmussen, I. G. Macintyre, and L. Prufert, "Modern stromatolite reefs fringing a brackish coastline, chetumal bay, Belize," Geology, vol. 21, no. 3, pp. 199-202, 1993.

[121] R. P. Reid, P. T. Visscher, A. W. Decho et al., "The role of microbes in accretion, lamination and early lithifi cation of modern marine stromatolites," Nature, vol. 406, pp. 989992, 2000.

[122] J. Reitner, J. Paul, G. Arp, and D. Hause-Reitner, "Lake thetis domal microbialites; a complex framework of calcified biofilms and organomicrites (cervantes, western Australia)," in Global and Regional Controls on Biogenic Sedimentation, J. Reitner, F. Neuweiler, and F. Gunkel, Eds., pp. 85-89, Geological Society of America, Boulder, CO, USA, 1996.

[123] N. Bridges, J. I. Núñez, F. P. Seelos, S. J. Hook, A. M. Baldridge, and B. J. Thomson, Mineralogy of Evaporite Deposits on Mars: Constraints from Laboratory, Field, and Remote Measurements of Analog Terrestrial Acid Saline Lakes, American Geophysical Union, Washington, DC, USA, 2015.

[124] A. V. Nguyen, A. M. Baldridge, and B. J. Thomson, "Microbial analysis of Australian dry lake cores," Analogs for Biogeochemical Processes, American Geophysical Union, Washington, DC, USA, 2014

[125] J. P. Grotzinger, "Deposition, exhumation, and paleoclimate of an ancient lake deposit, gale crater, Mars," Science, vol. 350, p. 6257, 2015.

[126] L. Le Deit, E. Hauber, F. Fueten, M. Pondrelli, A. P. Rossi, and R. Jaumann, "Sequence of infilling events in gale crater, mars: results from morphology, stratigraphy, and mineralogy," Journal of Geophysical Research, vol. 118, pp. 24392473, 2013.

[127] B. J. Thomson, N. T. Bridges, R. Milliken et al., "Constraints on the origin and evolution of the layered mound in gale crater, mars using mars reconnaissance orbiter data," Icarus, vol. 214, pp. 413-432, 2011.

[128] J. P. Grotzinger, J. A. Crisp, A. R. Vasavada, and M. S. L. Science Team, "Curiosity's mission of exploration at gale crater,” Elements, vol. 11, no. 1, pp. 19-26, 2015.

[129] S. Gupta, M. C. Malin, D. M. Rubin et al., "Deposition, exhumation, and paleoclimate of an ancient lake deposit, gale crater, Mars," Science, vol. 350, no. 6257, p. 12, 2015.

[130] D. Z. Oehler, "A periglacial analog for landforms in gale crater, Mars," in Proceedings of the Lunar and Planetary Science Conference, The Woodlands, TX; ,USA, 2013. 
[131] P. Masson, M. H. Carr, F. Costard et al., "Geomorphologic evidence for liquid water," Space Science Reviews, vol. 96, pp. 333-364, 2001.

[132] J. Frydenvang, P. J. Gasda, J. A. Hurowitz et al., "Diagenetic silica enrichment and late-stage groundwater activity in gale crater, Mars," Geophysical Research Letters, vol. 44, pp. 4716-4724, 2017.

[133] A.-M. Harri, "Mars Science laboratory relative humidity observations: initial results," JGR Planets, vol. 119, pp. 2132-2147, 2014.

[134] E. M. Hausrath, D. W. Ming, and E. B. Rampe, "Reactive transport and mass balance modeling of the stimson sedimentary formation and altered fracture zones constrain diagenetic conditions at gale crater, Mars," Earth and Planetary Science Letters, vol. 491, no. 1, pp. 1-10, 2018.

[135] A. S. Yen, D. W. Ming, D. T. Vaniman et al., "Multiple stages of aqueous alteration along fractures in mudstone and sandstone strata in gale crater, Mars," Earth and Planetary Science Letters, vol. 471, pp. 186-198, 2017.

[136] M. C. Malin and K. S. Edgett, "Evidence for persistent flow and aqueous sedimentation on early Mars," Science, vol. 302, no. 5652, pp. 1931-1934, 2003.

[137] M. T. R. J. Mellon, "Recent gullies on Mars and the source of liquid water," Journal of Geophysical Research, vol. 106, no. 10, pp. 23165-23180, 2001.

[138] P. Niles and J. Michalski, "Meridiani planum sediments on Mars formed through weathering in massive ice deposits," Nature Geoscience, vol. 2, pp. 215-220, 2009.

[139] R. M. E. Williams, "Martian fluvial conglomerates at gale crater," Science, vol. 340, pp. 1068-1072, 2013.

[140] J.-P. Bibring, Y. Langevin, J. F. Mustard et al., "Global mineralogical and aqueous mars history derived from omega/mars express data," Science, vol. 312, pp. 400-404, 2006.

[141] J. Buz, "Mineralogy and stratigraphy of the gale crater rim, wall, and floor units," Journal of Geophysical Research, vol. 122, pp. 1090-1118, 2017.

[142] N. A. Cabrol and E. A. Grin, "Distribution, classification, and ages of martian impact crater lakes," Icarus, vol. 142, no. 1, pp. 160-172, 1999.

[143] G. M. Martínez, “The modern near-surface martian climate: a review from in-situ meteorological data from viking to curiosity," Space Science Reviews, vol. 1, 2017.

[144] G. M. Martínez, "Likely frost events at gale crater: analysis from MSL/REMS measurements," Icarus, vol. 280, pp. 93102, 2015.

[145] S. L. Murchie, “A synthesis of martian aqueous mineralogy after 1 mars year of observations from the Mars reconnaissance orbiter," Journal of Geophysical Research, vol. 114, Article ID E00D06, 2009.

[146] K. L. Siebach and J. P. Grotzinger, "Volumetric estimates of ancient water on mount sharp based on boxwork deposits, gale crater, Mars," JGR Planets, vol. 119, pp. 189-198, 2014.

[147] F. Rivera-Hernandez, "Grain size variations in the murray formation: stratigraphic evidence for changing depositional environments in Gale crater, mars," JGR Planets, vol. 125, 2020.

[148] K. Fukushi, Y. Sekine, H. Sakuma et al., "Semiarid climate and hyposaline lake on early Mars inferred from reconstructed water chemistry at gale," Nature Communications, vol. 10, p. 4896, 2019.

[149] A. C. Allwood, M. R. Walter, B. S. Kamber, C. P. Marshall, and I. W. Burch, "Stromatolite reef from the early archaean era of Australia," Nature, vol. 441, pp. 714-718, 2006.
[150] R. Buick, J. S. R. Dunlop, and D. I. Groves, "Stromatolite recognition in ancient rocks: an appraisal of irregularly laminated structures in an early archean chert-barite unit from North pole, western Australia," Alcheringa, vol. 5, pp. 161-181, 1981.

[151] R. Buick, D. I. Groves, and J. S. R. Dunlop, "Comment on: abiological origin of described stromatolites older than 3.2 Ga," Geology, vol. 23, p. 191, 1995.

[152] D. R. Lowe, "A biological origin of described stromatolites older than 3," Geology, vol. 22, pp. 387-390, 1994.

[153] S. Bengtson, V. Belivanova, B. Rasmussen, and M. Whitehouse, "The controversial "cambrian" fossils of the vindhyan are real but more than a billion years older," Proceedings of the National Academy of Sciences, vol. 106, no. 19, pp. 7729-7734, 2009.

[154] T. Sallstedt, S. Bengtson, C. Broman, P. M. Crill, and D. E. Canfield, "Evidence of oxygenic phototrophy in ancient phosphatic stromatolites from the paleoproterozoic vindhyan and aravalli supergroups, India," Geobiology, vol. 16, no. 2, pp. 139-159, 2018

[155] S. W. Ruff, P. B. Niles, F. Alfano, and A. B. Clarke, "Evidence for a noachian-aged ephemeral lake in gusev crater, mars," Geology, vol. 42, no. 4, pp. 359-362, 2014.

[156] E. A. Grin and N. A. Cabrol, "Blimnologic analysis of gusev crater paleolake,” Icarus, vol. 130, no. 2, pp. 461-474, 1997.

[157] L. A. Haskin, "Water alteration of rocks and soils on Mars at the spirit rover site in gusev crater," Lettersm Nars, Nature, vol. 436, pp. 66-69, 2005.

[158] R. E. Arvidson, S. W. Squyres, R. C. Anderson et al., "Overview of the spirit mars exploration rover mission to gusev crater: landing site to backstay rock in the Columbia hills," Journal of Geophysical Research, vol. 111, Article ID E02S01, 2006.

[159] J. M. I. Richardson and M. A. Mischna, "Long-term evolution of transient liquid water on Mars," Journal of Geophysical Research, vol. 110, 2005.

[160] J. A. Hurowitz, S. M. McLennan, N. J. Tosca, D. W. Ming, and C. Schröder, "In situ and experimental evidence for acidic weathering of rocks and soils on Mars," Journal of Geophysical Research: Planets, vol. 111, Article ID E02S19, 2006.

[161] H. Y. McSween, "Basaltic rocks analyzed by the spirit rover in gusev crater," Science, vol. 305, pp. 842-845, 2004.

[162] R. V. Morris, G. Klingelhöfer, C. Schröder et al., "Mossbauer mineralogy of rock, soil, and dust at gusev crater, Mars: spirit's journey through weakly altered olivine basalt on the plains and pervasively altered basalt in the Columbia hills," Journal of Geophysical Research, vol. 111, Article ID E02S13, 2006.

[163] R. V. Morris, G. Klingelhöfer, C. Schröder et al., "Mossbauer mineralogy of rock, soil, and dust at Meridiani Planum, Mars: opportunity's journey across sulfate-rich outcrop, basaltic sand and dust, and hematite lag deposits," Journal of Geophysical Research, vol. 111, Article ID E12S15, 2006.

[164] A. Wang, "Sulfate deposition in subsurface regolith in gusev crater, mars," Journal of Geophysical Research, vol. 11, p. E2, 2006.

[165] C. T. Adcock and E. M. Hausrath, "Weathering profiles in phosphorus-rich rocks at gusev crater, mars, suggest dissolution of phosphate minerals into potentially habitable near-neutral waters," Astrobiology, vol. 15, p. 12, 2015.

[166] K. E. Herkenhoff, "Evidence from opportunity's microscopic imager for water on meridiani planum," Science, vol. 306, pp. 1727-1730, 2004. 
[167] G. Horneck, P. Rettberg, G. Reitz et al., "Protection of bacterial spores in space, a contribution to the discussion on panspermia," Origins of Life and Evolution of Biospheres, vol. 31, pp. 527-547, 2001.

[168] P. R. Christensen and S. W. Ruff, "Formation of the hematite-bearing unit in meridiani planum: evidence for deposition in standing water," JGR Planets, vol. 109, 2004.

[169] S. W. Squyres and A. H. Knoll, "Sedimentary rocks at Meridiani Planum: origin, diagenesis, and implications for life on mars," Earth and Planetary Science Letters, vol. 240, pp. 1-10, 2005.

[170] S. M. McLennan, J. F. Bell, W. M. Calvin et al., "Provenance and diagenesis of the evaporatebearing burns formation, Meridiani planum, mars," Earth and Planetary Science Letters, vol. 240, pp. 95-121, 2005.

[171] J. Andrews-Hanna, R. Phillips, and M. Zuber, "Planum and the global hydrology of Mars," Nature, vol. 446, pp. 163-166, 2007.

[172] S. W. Squyres, "Overview of the opportunity mars exploration rover mission to Meridiani Planum: eagle crater to purgatory ripple," Journal of Geophysical Research, vol. 111, Article ID E12S12, 2006.

[173] J. Kaźmierczak, “Ancient martian biomorphs from the rim of endeavour crater: similarities with fossil terrestrial microalgae," in Paleontology, Stratigraphy, Astrobiology, S. V. Rozhnov, Ed., pp. 229-242, Borissiak Paleontological Institute RAS, Moscow, Russia, 2016.

[174] S. D. Wall, "Analysis of condensates formed at the viking 2 lander site-the first winter," Icarus, vol. 47, pp. 173-183, 1981.

[175] K. Biemann, J. Oro, P. Toulmin et al., "The search for organic substances and inorganic volatile compounds in the surface of Mars," Journal of Geophysical Research: Planets, vol. 82, pp. 4641-4658, 1977.

[176] G. V. Levin, P. A. Straat, and W. D. Benton, "Color and feature changes at mars viking lander site," Journal of Theoretical Biology, vol. 75, pp. 381-390, 1978.

[177] B. E. DiGregorio, "Rock varnish as a habitat for extant life on mars," Instruments, Methods, and Missions for Astrobiology, vol. 4495, 2002.

[178] A. Steele, F. M. McCubbin, and M. Fries, "A reduced organic carbon component in martian basalts," Science, vol. 337, pp. 212-215, 2012.

[179] A. H. Treiman and E. J. Essen, "Chemical composition of magnetite in martian meteorite ALH 84001: revised appraisal from thermochemistry of phases in Fe-Mg-C-O," Geochimica et Cosmochimica Acta, vol. 75, pp. 5324-5335, 2011.

[180] S. J. Clement, M. T. Dulay, J. S. Gillette, X. D. Chillier, T. B. Mahajan, and R. N. Zare, "Evidence for the extraterrestrial origin of polycyclic aromatic hydrocarbons in the martian meteorite ALH84001," Faraday Discuss, vol. 109, pp. 417-436, 1998.

[181] D. S. McKay, K. L. Thomas-Keprta, S. J. Clemett, E. K. Gibson, L. Spencer, and S. J. Wentworth, "Life on Mars: new evidence from martian meteorites," Instruments and Methods for Astrobiology and Planetary Missions, vol. 7441, Article ID 744102, 2009.

[182] M. Wadhwa and G. W. Lugmair, "The formation age of carbonates in ALH 84001 (abstract)," Meteoritics, vol. 31, p. A145, 1996.

[183] I. Halevy and J. M. Eiler, "Carbonates in ALH 84001 formed in a short-lived hydrothermal system, $42^{\text {nd }}$ lunar and planetary science conference, held march 7-11, 2011 at the woodlands, Texas," LPI Contribution, vol. 1608, p. 2512, 2011.

[184] R. Shaheen, "Carbonate formation events in ALH 84001 trace the evolution of the martian atmosphere," PNAS, vol. 112, no. 2, pp. 336-341, 2015.

[185] A. A. Nemchin, M. J. Whitehouse, M. Menneken, T. Geisler, R. T. Pidgeon, and S. A. Wilde, "A light carbon reservoir recorded in zircon-hosted diamond from the jack hills," Nature, vol. 454, pp. 92-95, 2008.

[186] Y. T. Ohtomo, A. Kakegawa, and T. N. Ishida, "Evidence for biogenic graphite in early archaean isua metasedimentary rocks," Nature Geoscience, vol. 7, pp. 25-28, 2014.

[187] T. Tashiro, A. Ishida, M. Hori et al., "Early trace of life from $3.95 \mathrm{Ga}$ sedimentary rocks in labrador, Canada," Nature, vol. 549, no. 7673, pp. 516-518, 2017.

[188] S. J. Mojzsis, G. Arrhenius, K. D. McKeegan, T. M. Harrison, A. P. Nutman, and C. R. L. Friend, "Evidence for life on Earth before 3,800 million years ago," Nature, vol. 384, pp. 55-59, 1996.

[189] M. T. Rosing, "C-13-depleted carbon microparticles in $>3700$-Ma sea-floor sedimentary rocks from west Greenland," Science, vol. 283, pp. 674-676, 1999.

[190] M. T. Rosing and R. Frei, "U-rich Archaean sea-floor sediments from Greenland-indications of $>3700$ Ma oxygenic photosynthesis," Earth and Planetary Science Letters, vol. 217, pp. 237-244, 2004.

[191] M. A. Schidlowski, "3800-million-year isotopic record of life from carbon in sedimentary rocks," Nature, vol. 333, pp. 313-335, 1988.

[192] M. A. Schidlowski, "Carbon isotopes as biogeochemical recorders of life over $3.8 \mathrm{Ga}$ of Earth history: evolution of a concept," Precambr. Res, vol. 106, pp. 117-134, 2001.

[193] D. Paineau, S. J. Mozzsis, J. A. Karhu, and B. Marty, "Nitrogen isotopic composition of ammoniated phyllosilicates: case studies from Precambrian metamorphosed sedimentary rocks," Chemical Geology, vol. 216, pp. 37-58, 2005.

[194] A. D. Czaja, C. M. Johnson, B. L. Beard, E. E. Roden, W. Li, and S. Moorbath, "Biological Fe oxidation controlled deposition of banded iron formation in the ca. $3770 \mathrm{Ma}$ isua supracrustal belt (west Greenland)," Earth Planetary Science Letters, vol. 363, pp. 192-203, 2013.

[195] N. Dauphas, M. Van Zuilen, M. Wadhwa, A. M. Davis, B. Marty, and P. E. Janney, "Clues from the Fe isotope variations on the origin of early archean BIFs from Greenland," Science, vol. 306, pp. 2077-2080, 2004.

[196] H. D. Pflug, "Yeast-like microfossils detected in oldest sediments of the earth," Journal Naturwissenschaften, vol. 65, pp. 121-134, 1978.

[197] A. Y. Rozanov, "Review of exobiological research," Space Biology and Medicine, vol. 5, pp. 85-125, 2009.

[198] S. Arrhenius, Worlds in the Making, Harper \& Brothers, New York, NY, USA, 1908.

[199] F. Crick, Life Itself: Its Origin and Nature, Simon \& Schuster, New York, NY, USA, 1981.

[200] F. Hoyle, Evolution from Space (The Omni Lecture), Enslow Publishers, Berkeley Heights, NJ, USA, 1982.

[201] R. Joseph, "Life on earth came from other planets," Journal of Cosmology, vol. 1, pp. 44-77, 2009.

[202] R. Joseph and R. Schild, "Biological cosmology and the origins of life in the universe," Journal of Cosmology, vol. 10, pp. 40-75, 2010.

[203] M. Beech, M. Comte, and I. Coulson, "Lithopanspermia-the terrestrial input during the past 550 million years," American 
Journal of Astronomy and Astrophysics, vol. 7, no. 1, pp. 81-90, 2018.

[204] B. Gladman, J. A. Burns, M. Duncan, P. C. Lee, and H. F. Levison, "The exchange of impact ejecta between terrestrial planets," Science, vol. 271, pp. 1387-1392, 1996.

[205] B. Gladman, K. Dones, H. F. Levison, and J. A. Burns, "Impact seeding and reseeding in the inner solar system," Astrobiology, vol. 5, no. 4, pp. 483-496, 2005.

[206] H. J. Melosh, "Exchange of meteorites (and life?) between stellar systems," Astrobiology, vol. 3, pp. 207-215, 2003.

[207] C. Mileikowsky, F. A. Cucinotta, J. W. Wilson et al., "Natural transfer of viable microbes in space: part 1: from mars to earth and earth to mars," Icarus, vol. 145, pp. 391-427, 2000.

[208] R. Joseph, "Life on venus and the interplanetary transfer of biota from earth," Journal of Cosmology, vol. 27, pp. 1-18, 2019.

[209] R. De la Torre Noetzel, "Survival of lichens on the ISS-II: ultrastructural and morphological changes of Circinaria gyrosa after space and Mars-like conditions EANA2017," in Proceedings of the 17th European Astrobiology Conference, pp. 14-17, Aarhus, Denmark, 2017.

[210] R. De la Torre Noetzel, "Lichen vitality after a space flight on board the expose-r2 facility outside the international space station: results of the biology and mars experiment," Astrobiology, vol. 20, 2020.

[211] J.-P. De Vera, M. Alawi, T. Backhaus et al., "Limits of life and the habitability of mars: the ESA space experiment biomex on the ISS," Astrobiology, vol. 19, no. 2, pp. 145-157, 2019.

[212] G. Horneck, "Bacterial spores survive simulated meteorite impact," Icarus, vol. 149, p. 285, 2001.

[213] R. E. Riding, "A biogenic, microbial and hybrid authigenic carbonate crusts: components of Precambrian stromatolites," Geologia Croatica, vol. 61, pp. 73-103, 2008.

[214] D. Wacy, "Stromatolites in the $\sim 3400 \mathrm{Ma}$ strelley pool formation, western Australia: examining biogenicity from the macro- to the nano-scale," Astrobiology, vol. 10, 2010. 